\title{
PENGARUH KAPASITAS SUMBER DAYA MANUSIA, PEMANFAATAN TEKNOLOGI INFORMASI DAN PENGENDALIAN INTERN TERHADAP KETEPATWAKTUAN PELAPORAN KEUANGAN DESA (STUDI PADA DESA DI KABUPATEN ACEH SELATAN)
}

\author{
Agung Muhammad Arighi ${ }^{1}$, Darwanis ${ }^{* 2}$ \\ ${ }^{1,2}$ Program Studi Akuntansi Fakultas Ekonomi dan Bisnis Universitas Syiah Kuala \\ e-mail: agungmarg@gmail.com ${ }^{1}$,darwanis.fe@ unsyiah.ac.id ${ }^{2}$
}

\section{* Corresponding Author}

\begin{abstract}
Abstrak
This research aims to test the influence of human resources Capacity, utilization of information technology as well as internal control against the timeliness of financial reporting village. The population in this research is the entire village in Aceh Selatan Regency. Sampling techniques in the study is simple random sampling. The research of using primary data obtained through the filling of the questionnaire. The data collected as many as 73 a detailed questionnaire from the 260 villages that existed in South Aceh Regency. Data processing using SPSS tool Version 22. Statistical analysis is used in logistic regression is. The results showed that collectively the variable capacity of human resources, utilization of information technology as well as internal control against the timeliness of financial reporting village. Each partially independent variable affect the timeliness of financial reporting Village.
\end{abstract}

Keywords: Human Resource Capacity, Utilization of Information Technology, Internal Control, Timeliness of Financial Reporting Village

\section{Pendahuluan}

Pemerintah pusat ataupun pemerintah daerah mempunyai kewajiban menyajikan informasi yang berkaitan dengan laporan keuangan. Laporan keuangan yang dilaporkan harus disusun menurut Standar Akuntansi Pemerintah sesuai dengan (Wansyah, Darwanis, \& Bakar, 2012) serta didalamnya harus memenuhi unsur tepat waktu. Dalam pelaporan keuangan pemerintah terdapat karakteristik kualitatif yang merupakan syarat yang normatif sebagaimana yang terdapat pada "Rerangka Konseptual Akuntansi Pemerintah yaitu: (1) relevan, (2) andal, (3) dapat dibandingkan, dan (4) dapat dipahami. Apabila informasi yang terdapat pada Laporan Keuangan Pemerintah Daerah sudah sesuai dengan kriteria karakteristik kualitatif, maka pemerintah desa akan mampu mewujudkan akuntabilitas serta transparansi dalam pengelolaan keuangan desa. Adapun laporan keuangan yang relevan apabila terdapat (1) manfaat umpan balik (feedback value), (2) manfaat prediktif (predictitive value), (3) tepat waktu (timeliness), dan (4) lengkap" (Trisaputra, 2013).

Ketepatwaktuan adalah tersedianya informasi yang berkaitan dengan laporan keuangan, yang nanti akan digunakan oleh para pembuat keputusan, semakin lama informasi tersedia akan membuat informasi kehilangan kekuatannya. Dalam beberapa hal, mengejar ketepatwaktuaan secara tidak langsung akan mengurangi kualitas yang lain (Wansyah et al., 2012). Menurut (Mamduh, 2003) dalam (Trisaputra, 2013) ketepatwaktauan pelaporan keuangan menjadi penting untuk di perhatikan. Jika pelaporan laporan keuangan tepat waktu ataupun terlambat, maka manfaat laporan keuangan serta relevansi akan berkurang.

Didampingi PPK Satker P3MD Aceh, T Zul Husni, Amhar kepala Dinas DPMG Aceh kepada Serambi kemarin menyebutkan hingga Jumat (13/4), baru 761 gampong (11,71 persen) yang sudah menerima dana desa tahap I Sedangkan jumlah gampong di Aceh 6.497. "Padahal kalau sudah April, dana desa tahap pertama ini belum bisa dicairkan, kapan lagi kerjanya. Sedangkan pertengahan bulan 
depan sudah masuk bulan Ramadhan," kata Amhar. Terdapat 10 penyebab terlambatnya pelaporan keuangan desa, adapun salah satu penyebab itu, kata Amhar, pertama terlambatnya penyampaian laporan keuangan desa anggaran sebelumnya (laporan pertanggungajawan) pelaksanaan dana desa tahun 2017 oleh perangkat desa (Serambinews.com, 2018).

Kabupaten Aceh Selatan yang dengan ibu kota Tapaktuan ini merupakan salah satu kabupaten penerima dana desa dengan jumlah lumayan tinggi diantara kabupaten-kabupaten yang ada di Aceh, sudah sepatutnya pengelolaan serta pelaporan pertanggung jawaban dana dilakukan dengan sangat baik dan tepat waktu. Namun, pada kenyataannya pelaporan Laporan Pertanggung Jawaban dana desa masih menjadi kendala utama. Dari total 260 desa yang ada di Kabupaten Aceh Selatan hingga bulan agustus 2018 masih terdapat 13 desa yang belum lengkap melaporkan LPJ tahun 2017 kepada Dinas DPMG Selatan. Ini menjadi penyebab terkendalanya pencairan dana desa Tahap II di Aceh Selatan tahun 2018.

Pemerintah desa memiliki tanggungjawab untuk menyampaikan laporan keuangan tepat waktu. Pada dasarnya akan banyak informasi yang terdapat dalam laporan keuangan desa akan banyak digunakan oleh stakeholder, yang berguna untuk pengambilan keputusan tertentu (Mirnayanti, Bandang, \& Damayanti, 2013). Untuk itu unsur ketepatwaktuan harus terpenuhi pada pelaporan keuangan desa sehingga informasi yang disampaikan secara tepat waktu dapat berpangaruh serta berguna. Berapa tinjauan tentang ketepatwaktuan penyajian laporan keuangan desa kami duga terdapat variabel-variabel yang mempengaruhi variabel dependen tersebut, yaitu sumber daya manusia, pemanfaatan teknologi informasi dan pengendalian intern.

Kinerja dari sumber daya yang tersedia akan terlihat dari pelaksanaan fungsi yang akan berdampak secara langsung pada efektifitas serta efesiensi kerja dalam mencapai tujuan , Kemampuan seorang, individu, suatu organisasi juga sistem akan sangat berpengaruh terhadap keluaran-keluaran (output) serta hasil-hasil (outcomes). Sumber daya manusia akan sangat dibutuhkan untuk mempercepat penyusunan laporan keuangan pemerintah desa, sehingga laporan keuangan tersebut dapat tersaji tepat waktu (Winidyaningrum \& Rahmawati, 2010).
Penelitian(Arina Roshanti Edy Sujana \& Kadek Sinarwati, 2014) "menunjukkan bahwa kualitas sumber daya manusia berpengaruh signifikan terhadap keterandalan dan ketepatwaktuan pelaporan keuangan pemerintah daerah".

Menurut (Jurnali \& Supomo, 2002) "pemanfaatan teknologi informasi merupakan tingkat integrasi teknologi informasi terhadap pelaksanaan tugas-tugas akuntansi. Pemanfaatan teknologi informasi mencakup adanya (a) pengolahan informasi, pengolahan data, proses kerja secara elektronik serta sistem manajemen dan pemanfaatan kemajuan teknologi informasi dilaksanakan agar pelayanan public menjadi mudah serta murah untuk diakses oleh masyarakat di seluruh wilayah negeri ini" (Hamzah, 2010). Penelitian (Tyas, 2014) "berhasil menunjukkan bahwa pemanfaatan teknologi informasi berpengeruh signifikan dan positif terhadap ketepatwaktuan pelaporan keuangan pemerintah daerah. Juga pada penelitian (Ariesta, 2013) menujukkan hasil yang serupa terdapat hubungan positif antara pemanfaatan teknologi informasi terhadap ketepatwaktuan pelaporan keuangan pemerintah daerah".

Pengendalian intern diperlukan dalam kegiatan pemerintah dengan tujuan agar segala tujuan pemerintah yang selama ini telah di tetapkan dapat tercermin dari tingkat ketangkasan dalam pengendalian laporan keuangan, efesiensi, efektivitas pelaksanaan program serta tingkat kepatuhan terhadap undangundang Penelitian yang dilakukan oleh (Tyas, 2014) "menyatakan hasil bahwa pengendalian intern berpengaruh terhadap ketepatwaktuan pelaporan keuangan daerah".

Berdasarkan uraian latar belakang tersebut, maka penulis mengajukan penelitian yang berjudul "Pengaruh Kualitas Sumber Daya Manusia, Pemanfaatan Teknologi Informasi serta Pengendalian Intern terhadap Ketepatwaktuan Pelaporan Keuangan Desa (Studi Pada Desa di Kabupaten Aceh Selatan)

\section{Perumusan Masalah}

Berdasarkan latar belakang yang telah diungkapkan, maka rumusan masalah yang akan diteliti dalam penelitian ini adalah: 
1. Apakah kapasitas sumber daya manusia berpengaruh terhadap ketepatwaktuan pelaporan keuangan desa di Kabupaten Aceh Selatan.

2. Apakah pemanfaatan teknologi informasi berpengaruh terhadap ketepatwaktuan pelaporan keuangan desa di Kabupaten Aceh Selatan.

3. Apakah kualitas sistem berpengaruh terhadap kepuasan pengguna Siskeudes di Kabupaten Aceh Besar?

4. Apakah kebergunaan sistem berpengaruh terhadap kepuasan pengguna Siskeudes di Kabupaten Aceh Besar?

\section{Tujuan Penelitan}

Tujuan penelitian ini adalah untuk mendapatkan bukti secara empiris dan menganalisis terhadap hal-hal sebagai berikut:

1. Untuk menguji apakah kapasitas sumber daya manusia berpengaruh terhadap ketepatwaktuan pelaporan keuangan desa di Kabupaten Aceh Selatan.

2. Untuk menguji apakah pemanfaatan teknologi informasi berpengaruh terhadap ketepatwaktuan pelaporan keuangan desa di Kabupaten Aceh Selatan.

3. Untuk menguji apakah pengendalian intern berpengaruh terhadap ketepatwaktuan pelaporan keuangan desa di Kabupaten Aceh Selatan.

4. Untuk menguji apakah kapasitas sumber daya manusia, pemanfaatan teknologi informasi, dan pengendalian intern secara bersama-sama berpengaruh terhadap ketepatwaktuan pelaporan keuangan desa di kabupaten Aceh Selatan.

\section{Kerangka Teoritis dan Pengembangan Hipotesis Tinjauan Pustaka \\ Pelaporan Keuangan}

Menurut (Suwardjono, 2005:168) Pelaporan keuangan merupakan proses penyampaian informasi yang dilakukan sesuai dengan kaidah akuntansi yang berfungsi untuk mencapai tujuan ornagisasi. Menurut Ikatan Akuntansi Indonesia (2012:5) "laporan keuangan merupakan struktur yang menyajikan posisi keuangan dan kinerja keuangan dalam sebuah entitas. Laporan keuangan pada dasarnya adalah bentuk pertanggung jawaban pemerintah dalam hal menyajikan informasi keuangan sebagai bentuk untuk menunjukkan akuntabilitas entitas pelaporan serta akan berguna untuk pengambilan"

\section{Pelaporan Keuangan Desa}

Menurut (Permendagri No 113 Tahun, 2014) Pasal 37 menyatakan "bahwa kepala desa memiliki kewajiban menyampaikan laporan realisasi pelaksanaan APBDesa kepada Bupati/Walikota berupa, pertama laporan semester pertama yaitu berupa laporan realisasi APBDesa yang menggambarkan realisasi pendapatan, belanja, dan pembiayaan selama pelaksanaan pada semester pertama serta disampaikan selambat-lambatnya disampaikan pada akhir bulan juli tahun berjalan. Kedua laporan semeter semester akhir tahun berupa realisasi pendapatan, belanja, dan pembiayaan sampai akhir tahun yaitu bersifat akumulatif dari awal hingga akhir tahun dan disampaikan paling lambat 1 (satu) bulan setelah tahun anggaran".

\section{Ketepatwaktuan Pelaporan Keuangan Desa}

Ketepatwaktuan adalah tersedianya informasi yang berkaitan dengan laporan keuangan, yang nanti akan digunakan oleh para pembuat keputusan, semakin lama informasi tersedia akan membuat informasi kehilangan kekuatannya. Setelah Tersedianya informasi dalam waktu yang lama setelah suatu kejadian kemudian akan diperlukan suatu tanggapan apabila sudah terlaulama maka akan menjadikan informasi tersebut tidak punya nilai lagi. (Suwardjono, 2005:79).

\section{Kapasitas Sumber Daya Manusia}

Kapasitas sumber daya manusia adalah cara yang dilakukan oleh individu guna mencapai tujuan sesuai dengan tugas-tugas pokok serta kewenangannya secara efektif dan efisien. Kapasitas juga dapat dilihat dari inovasi yang dilakukan oleh guna menghasilkan tujuan-tujuan yang akan berdampak pada kesejahteraan organisasi (Indriasari \& Narhatyo, 2008).

\section{Pemanfaatan Teknologi Informasi}

Pada Permendagri No. 56 Tahun 2010 "dijelaskan bahwa sistem akuntansi pemerintahan daerah meliputi serangkaian prosedur mulai dari proses pengumpulan data, pencatatan, pengikhtisaran, sampai dengan pelaporan keuangan dalam rangka 
pertanggungjawaban pelaksanaan APBD yang dapat dilakukan secara manual atau menggunakan aplikasi komputer. Pemanfaatan teknologi informasi mencakup adanya:

1. Pengolahan data, pengolahan informasi, sistem manajemen, dan proses kerja secara elektronik, dan

2. Pemanfaatan kemajuan teknologi informasi agar pelayanan publik dapat diakses secara mudah dan murah oleh masyarakat".

\section{Pengendalian Intern}

Menurut (PP No 60 Tahun 2008) "tentang Sistem Pengendalian Intern Pemerintah (SPIP) mendefinisikan pengendalian intern sebagai proses yang integral pada tindakan dan kegiatan yang dilakukan secara terus menerus oleh pimpinan dan seluruh pegawai untuk memberikan keyakinan memadai atas tercapainya tujuan organisasi melalui kegiatan yang efektif dan efisien, keandalan pelaporan keuangan, pengamanan aset negara, dan ketaatan terhadap peraturan perundangundangan.”

\section{Penelitian Terdahulu}

Bagi instansi pemerintahan diharapkan agar dapat meningkatkan kualitas kinerjanya dalam hal pengelolaan keuangan dengan memperhatikan dan meningkatkan kualitas sumberdaya manusia yang dimiliki serta didukung dengan pemanfaatan teknologi informasi seoptimal mungkin dan adanya rancangan pengendalian intern akuntansi yang memadai agar menghasilkan laporan keuangan pemerintah daerah yang bernilai yaitu keterandalan dan ketepatwaktuan. Penelitian ini berjudul "pengaruh sumber daya manusia, pemanfaatan teknologi informasi dan pengendalian internal terhadap ketepatwaktuan pelaporan keuangan daerah studi empiris pada Dinas Pendapatan, Pengelolaan Keuangan dan Aset Daerah di Wilayah Eks Karesidenan Surakarta.. Responden dalam penelitian ini adalah pegawai Dinas Pendapatan, Pengelolaan Keuangan dan Aset Daerah di wilayah Eks Karesidenan Surakarta”.

\section{Kerangka Pemikiran}

Kerangka pemikiran pada penelitian ini berguna untuk menjelaskan pengaruh antara variabel independen yaitu: Kapasitas Sumber Daya Manusia (X1), Pemanfaatan Teknologi Informasi (X2), dan
Pengendalian Intern (X3) terhadap Ketepatwaktuan Pelaporan Keuangan Desa (Y).

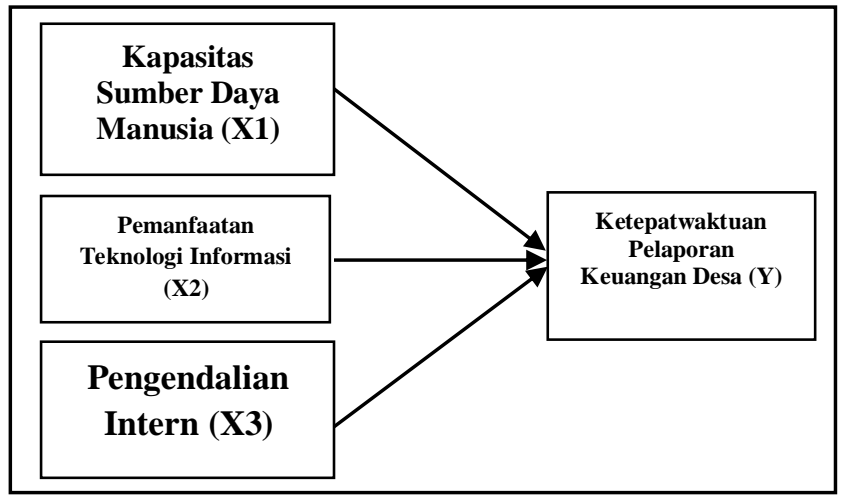

Gambar 2.1 Skema Kerangka Penelitian

\section{Hipotesis}

Berdasarkan kajian pustaka dan kerangka pemikiran, maka hipotesis pada penelitian ini adalah:

H1: Kapasitas sumber daya manusia berpengaruh terhadap ketepatwaktuan pelaporan keuangan desa di Kabupaten Aceh Selatan.

H2: Pemanfaatan teknologi berpengaruh terhadap ketepatwaktuan pelaporan keuangan desa di Kabupaten Aceh Selatan.

H3: Pengendalian intern berpengaruh terhadap ketepatwaktuan pelaporan keuangan desa di Kabupaten Aceh Selatan.

H4: Kapasitas Sumber Daya Manusia, Pemanfaatan Teknologi Informasi serta Pengendalian Intern terhadap ketepatwaktuan pelaporan keuangan desa

\section{Metode Penelitian}

\section{Desain Penelitian}

Pada penelitian ini tujuannya adalah untuk melakukan pengujian hipotesis. Sedangkan jenis investigasi yang digunakan pada penelitian ini adalah studi kasual (Causal Study). Pada penelitian ini menggunakan tingkat intervensi minimal. Sedangkan untuk situasi studinya tidak diatur. Unit analisis yang digunakan adalah unit organisasi, yaitu desa di Kabupaten Aceh Selatan. Penelitian ini menggunakan data primer yaitu penelitian lapangan. Dalam penelitian ini horizon waktu yang digunakan studi cross sectional. (Sekaran, 2006:177)

\section{Populasi dan Sampel}

Pada penelitian ini populasinya adalah desa 
diseluruh di Kabupaten Aceh Selatan sebanyak 260 desa. Teknik pengambilan sampel yang digunakan adalah teknik simple random sampling. (Sudarmanto, 2013:49). "simple random sampling adalah teknik pengambilan sampel dari populasi secara acak, dimana setiap anggota populasi memiliki kesempatan yang sama untuk dipilih menjadi sampel. Penentuan jumlah sampel dalam penelitian ini didasarkan pada teori Slovin yang dijabarkan dengan rumus sebagai berikut”:

$$
\mathrm{N}: \frac{\mathrm{n}}{1+\mathrm{N} \cdot \mathrm{e}^{2}}
$$

Keterangan :

$$
\begin{aligned}
& \mathrm{n} \quad=\text { Jumlah sampel } \\
& \mathrm{N} \quad=\text { Jumlah populasi } \\
& 1=\text { Konstanta } \\
& \text { e } \quad=\text { Margin of error (kesalahan maksimum yang }
\end{aligned}
$$

$$
\begin{gathered}
n=\frac{260}{1+260(0,1)^{2}} \\
n=\frac{260}{1+260(0,01)} \\
n=\frac{260}{1+2.60} \\
n=\frac{260}{3.60} \\
n=72,22
\end{gathered}
$$

\begin{tabular}{|c|c|c|}
\hline \multicolumn{3}{|c|}{ Operasionalisasi Variabel } \\
\hline Variabel & Indikator & Skala \\
\hline $\begin{array}{c}\text { Kapasitas } \\
\text { Sumber Daya } \\
\text { Manusia }\end{array}$ & 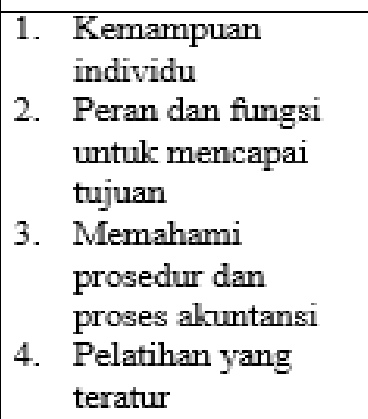 & Interval \\
\hline $\begin{array}{l}\text { Pemanfaatan } \\
\text { Teknologi }\end{array}$ & 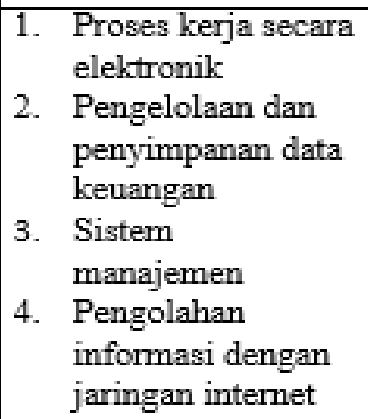 & Interval \\
\hline $\begin{array}{l}\text { Pengendalian } \\
\text { Intern }\end{array}$ & $\begin{array}{l}\text { 1. Perancangan yang } \\
\text { memadai } \\
\text { 2. Pemisahan } \\
\text { wewenang } \\
\text { 3. Tindakan disiplin } \\
\text { atas pelanggaran }\end{array}$ & Interval \\
\hline $\begin{array}{c}\text { Ketepatwaktua } \\
\text { n Pelaporan } \\
\text { Keuangan } \\
\text { Desa } \\
\end{array}$ & 1. Tepat waktu & Dummy \\
\hline
\end{tabular}

\section{Metode Pengumpulan Data}

Jenis data yang pada penelitian ini adalah data primer. (Sekaran, 2006:77). Data primer merupakan data yang diambil secara aktual dilapangan melalui penyebaran kuesioner diperuntukkan pada setiap sample. Kuesioner terdiri dari 1 (satu) variabel terikat dan 3 (tiga) variabel bebas.

\section{Metode Analisis}

Regresi logistik pada dasarnya sama dengan regresi berganda, bedanya variabel terikatnya merupakan non-metrik, sedangkan variabel bebasnya metrik. Pada teknik regresi logistik tidak lagi menggunaka uji normalitas (Ghozali, 2016).

$\operatorname{Ln}(1-p)=a+b 1 X_{1}+b 2 X_{2}+b 3 X_{3}+\ldots . .+\varepsilon$

Keterangan :

Ln $(1-p)=$ Log dari perbandingan antara tepat waktunya pelaporan keuangan desa dengan tidak tepat waktunya pelaporan keuangan desa

$\mathrm{a}=$ Konstanta

b1 = Koefisien regresi dari Kapasitas SDM

b2 $=$ Koefisien regresi dari Pemanfaatan TI

b3 $=$ Koefisien regresi dari Pengendalian Intern

$\varepsilon=$ Error 


\section{Hasil Dan Pembahasan Penyebaran Kuesioner}

Pada penelitian ini, pengumpulan data melalui penyebaran kuesioner langsung kepada bendahara desa yang berada di 10 Kecamatan pada Kabupaten Aceh Selatan. Penyebaran kuesioner dilakukan sejak tanggal 6 Januari 2019 yang membutuhkan waktu selama 12 hari sampai tanggal 18 Januari 2019 untuk mengumpulkan seluruh kuesioner.

Sesuai dengan fakta penelitian ini dari 85 kuesioner yang disebar hanya sebanyak 73 responden yang mengisi kuesioner atau hanya $86 \%$ kuesioner yang kembali. 12 kuesioner tidak kembali dikarenakan kuesioner tidak diisi oleh responden atau kuesioner memang tidak dikembalikan oleh responden. Seluruh data yang diolah menggunakan program SPSS (Statistical Package for Social Science) 22.

\section{Karakteristik Responden}

Adapun karakteristik responden pada penelitian ini terdapat lebih banyak laki-laki dibandingkan perempuan, yaitu 62 responden $(85.9 \%)$ sementara responden perempuan hanya berjumlah 11 orang (14.1\%). Responden kemudian dikelompokkan berdasarkan usia diketahui bahwa mayoritas responden berusia 30 - 50 tahun yaitu sebanyak (45.2\%), Usia <30 sebanyak 28,7\% dan terakhir yang berusia $>50$ sebanyak $26.1 \%$. Tingkat pendidikan responden diketahui berpendidikan SMA Yaitu (39.7\%) , D3 sebanyak 32,9\% kemudian S1 sebanyak $27.4 \%$ Selanjutnya berdasarkan masa kerja, diketahui bahwa paling banyak masa kerja 3-5 tahun sebanyak (37\%), untuk yang bermasa kerja 1-3 tahun sebanyak $35.6 \%$

\section{Hasil Pengujian \\ Hasil Pengujian Validitas}

Dinyatakan bahwa seluruh pernyataan yang diuji adalah valid. Pernyataan tersebut didasari oleh hasil uji validitas yang menunjukkan bahwa nilai $(\mathrm{N}=73)$ lebih besar dari 0,235 , nilai tersebut dapat dilihat dari tabel $\mathrm{r}$ product-moment.

\section{Hasil Pengujian Reliabilitas}

Berdasarkan hasil pengujian reliabilitas menyatakan bahwa variabel kapasitas sumber daya manusia (X1) memperoleh nilai Cronbach Alpa sebesar 0,722, variabel Pemanfaatan Teknologi Informasi (X2) memperoleh Cronbach Alpa sebesar 0,793, variabel Pengendalian Intern (X3) memperoleh nilai Cronbach Alpasbesar 0,619, dan variabel Ketepatwaktuan pelaporan keuangan desa juga memperoleh hasil sebesar 0,713.

\begin{tabular}{|l|l|l|}
\hline Variabel & Hasil Cronbach & Keterangan \\
\hline $\begin{array}{l}\text { Kapasitas Sumber } \\
\text { Daya Manusia }\end{array}$ & $0.722>0,60$ & Realiabel \\
\hline $\begin{array}{l}\text { Pemanfaatan } \\
\text { Teknologi } \\
\text { Informasi }\end{array}$ & $0.793>0,60$ & Realiabel \\
\hline $\begin{array}{l}\text { Pengendalian } \\
\text { Intern }\end{array}$ & $0,619>0,60$ & \\
\hline $\begin{array}{l}\text { Ketepatwaktuan } \\
\text { Pelaporan } \\
\text { Keuangan Desa }\end{array}$ & $0,713>0,60$ & Realiabel \\
\hline
\end{tabular}

Hasil Analisis Regresi Logistik

\begin{tabular}{|l|r|r|r|r|r|}
\hline & & & & \multicolumn{2}{|c|}{$95.0 \%$ C.I for } \\
& & B & Sig. & Exp(B) (B) & \multicolumn{2}{|c|}{$\begin{array}{l}\text { Lowe } \\
\text { I }\end{array}$} & $\begin{array}{l}\text { Uppe } \\
\mathrm{r}\end{array}$ \\
\hline Kapasitas & 3.371 & .004 & 29.112 & 2.922 & 290.1 \\
SDM & & & & & 0 \\
Pemanfaatan & 1.572 & .043 & 4.605 & 1.049 & $\begin{array}{r}20.21 \\
2\end{array}$ \\
TI & & & & & 110.4 \\
Pengendalian & 2.672 & .010 & 14.469 & 1.896 & $\begin{array}{r}110 \\
\text { Intern }\end{array}$ \\
Constant & 26.10 & .000 & .000 & & \\
& 9 & & & & \\
\hline
\end{tabular}

a. Dependen Variabel : Ketepatwaktuan Pelaporan Keuangan Desa

Hasil pengolahan SPSS (coefficients) melalui persamaan menurut Regresi diperoleh hasil sebagai berikut:

$$
\begin{aligned}
\operatorname{Ln}(1-p)= & 26.109+3,371 X 1+1.572 X 2+ \\
& 02.672 X 3+e
\end{aligned}
$$

\section{Pengujian Signifikan Simultan (Uji Omnibus)}

Berdasarkan hasil pengujiannya menunjukkan besaran Signifikansi sebesar 0.00 lebih rendah disbanding tingkat signifikansinya 0.05 maka dinyatakan bahwa kapasitas sumber daya manusia, pemanfaatan teknologi informasi serta pengendalian intern secara simultan berpengaruh terhadap ketepatwaktuan pelaporan keuangan desa.

\section{Pengujian Signifikan Parsial (Uji Wald)}

Berdasarkan nilai wald kapasitas sumber daya manusia adalah sebesar 8.259 (sig. 0,004). Menunjukkan nilai signifikansi yang lebih rendah 
dibandingkan tingkat signifikansi 0,05 . Dapat disimpulkan hipotesis diterima. variabel kapasitas sumber daya manusia berpengaruh signifikan terhadap ketepatwaktuan pelaporan keuangan desa.

Berdasarkan nilai wald pemanfaatan teknologi informasi adalah sebesar 4,096 (sig. 0.043), menunjukkan bahwa nilai signifikansi lebih rendah dari tingkat signifikansi (0.05) 5\%. Dari hasil tersebut dapat dinyatakan bahwa hipotesis diterima. Variabel pemanfaatan teknologi berpengaruh signifikan terhadap ketepatwaktuan pelaporan keuangan desa..

Berdasarkan tabel 4.18, nilai wald pengendalian intern 6,640 (sig. 0,010). Menyatakan bahwa nilai signifikansi lebih rendah dari (0.05) $5 \%$ sehingga dapt dinyatakan hipotesis diterima. variabel untuk pengendalian intern dapat diterima, Artinya, pengendalian intern mempunyai pengaruh yang signifikan terhadap ketepatwaktuan pelaporan keuangan desa.

\section{Pembahasan}

Pengaruh Kapasitas Sumber Daya Manusia, Pemanfaatan Teknologi Informasi dan Pengendalian Intern terhadap Ketepatwaktuan Pelaporan Keuangan Desa

Berdasarkan hasil pengujian secara simultan "sumber daya manusia, pemanfaatan teknologi informasi dan pengendalian intern berpengaruh terhadap ketepatwaktuan pelaporan keuangan desa pada desa di kabupaten Aceh Selatan. Sesuai dengan hipotess yang sudah dirancang, yakni kapasitas sumber daya manusia, pemanfaatan teknologi informasi dan pengendalian intern berpengaruh secara bersama-sama terhadap ketepatwaktuan pelaporan keuangan desa. Menunjjukan bahwa semua variabel independent mapu meningkatkan ketepatwaktuan pelaporan keuangan desa. Hasil ini sejalan dengan penelitian oleh (Yosefrinaldi, 2013) dan penelitian (Ariesta, 2013) menunjukkan hasil Pengaruh Kualitas Sumber Daya Manusia, Pemanfaatan Teknologi Informasi, dan Pengendalian Intern Akuntansi secara simultan berpengaruh terhadap Nilai Informasi Pelaporan Keuangan Pemerintah Daerah”.

\section{Pengaruh Kapasitas Sumber Daya Manusia terhadap Ketepatwaktuan Pelaporan Keuangan Desa}

Berdasarkan hasil regresi logistik dengan menggunakan uji wald, nilai koefisien regresi menunjukkan bahwa kapasitas sumber daya manusia berpengaruh terhadap ketepatwaktuan pelaporan keuangan desa di Kabupaten Aceh Selatan. Sejalan dengan hipotesis yang telah dirancang, yakni kapasitas sumber daya manusia berpengaruh terhadap ketepatwaktuan pelaporan keuangan desa di Kabupaten Aceh Selatan. Hasil penelitian ini sesuai dengan penelitian yang dilakukan oleh (Mirnayanti et al., 2013) dan (Tyas, 2014) "menunjukkan bahwa kapasitas sumber daya manusia berpengaruh positif terhadap kualitas laporan keuangan pemerintah daerah.

Dengan meningkatkan kapasitas sumber daya manusia yang baik dalam bidang akuntansi, memudahkan pemerintah desa untuk melaksakanan tugas-tugasnya serta membantu mempercepat proses pelaporan keuangan desa.

\section{Pengaruh Pemanfaatan Teknologi Informasi Ketepatwaktuan Pelaporan Keuangan di Kabupaten Aceh Selatan}

Berdasarkan hasil regresi Logistik dengan menggunakan uji wald, nilai koefisien regresi menunjukkan bahwa pemanfaatan teknologi informasi berpengaruh terhadap ketepatwaktuan pelaporan keuangan di Kabupaten Aceh Selatan. Sejalan dengan hipotesis yang telah dirancang, yakni pemanfaatan teknologi Informasi berpengaruh terhadap ketepatwaktuan pelaporan keuangan di Kabupaten Aceh Selatan. Hasil penelitian ini sejalan dengan hasil penelitian yang sudah dilakukan oleh (Winidyaningrum \& Rahmawati, 2010) dan (Yosefrinaldi, 2013) dapat disimpulkan bahwa pemanfaatan teknologi informasi berpengaruh positif terhadap kualitas laporan pemerintah daerah.

Pemanfaatan teknologi informasi dirasa sangat membantu perangkat desa dalam melaksanakannya, sehingga memudahkan para perangkat desa dalam proses pembuatan laporan keuangan. Dengan demikian pemanfaatan teknologi informasi menjadi factor yang menunjang ketepatwaktuan pelaporan keuangan desa. 


\section{Pengaruh Pengendalian Intern terhadap Ketepatwaktuan Pelaporan Keuangan di Kabupaten Aceh Selatan}

Berdasarkan hasil regresi linear Logistik dengan menggunakan uji wald, "nilai koefisien regresi menyatakan pengendalian intern berpengaruh terhadap ketepatwaktuan pelaporan keuangan di Kabupaten Aceh Selatan. Sejalan dengan hipotesis yang sudah dirancang, yakni pengendalian intern berpengaruh terhadap ketepatwaktuan pelaporan keuangan di Kabupaten Aceh Selatan. Hasil pada penelitian ini sesuai dengan penelitian (Tyas, 2014) dan (Yudiananta \& Erawati, 2012) yang menunjukkan hasil bahwa pengendalian intern akuntansi berpengaruh positif terhadap kualitas nilai informasi akuntansi.

Pengendalian intern dibuat untuk mengurangi terjadinya kesalahan serta kekeliruan yang terjadi saat membuat laporan pertanggjawaban realisasi APBdes, dengan adanya pengendalin intern diharapkan mampu memberi efek langsung terhadap ketepatwaktuan pelaporan keuangan desa. Dengan adanya pengendalian intern yang mumpuni makan akan menghasilkan pelaporan keungan desa secara tepat waktu.

\section{Kesimpulan, Keterbatasan dan saran Kesimpulan}

Hasil dari pembahasan penelitian menyatakan bahwa :

1) Kapasitas sumber daya manusia, pemanfaatan teknologi informasi, serta pengendalian intern berpengaruh signifikan terhadap ketepatwaktuan pelaporan keuangan desa di Kabupaten Aceh. Hal ini menunjukan bahwa dengan meningkatkan kapasitas sumber daya manusia, meningkatkan pemanfaatan teknologi informasi serta didukung pengendalian intern yang baik akan pemerintah desa akan mampu menyajikan laporan keuangan desa secara tepat waktu

2) Kapasitas Sumber Daya Manusia berpengaruh signifikan terhadap ketepatwaktuan pelaporan keuangan desa di kabupaten Aceh Selatan. Hal ini menunjukkan bahwa apabila sumber daya manusia dapat ditinggkan kapasitasnya maka semakin baik pula pemerintah desa dalam menyajikan laporan keuangan desa secara tepat waktu.
3) Pemanfaatan teknologi informasi berpengaruh signifikan terhadap ketepatwaktuan pelaporan keuangan desa. Hal ini menunjukkan bahwa pemanfaatan teknologi sudah diterapkan" secara"efektif dan efisien mungkin guna membantu perangkat desa dalam hal ini bendahara desa dalam membuat laporan keuangan

4) Pengendalian Intern berpengaruh positif terhadap ketepatwaktuan pelaporan keuangan desa. Hal ini menunjukkan bahwa sistem pengendalian intern telah dilaksanakan secara baik serta optimal, lebih dari sekedar itu pemerintah desa telah mampu menetapkan serta menjalan tugas masingmasing secara baik, hal ini mendukung penyajian pelaporan keuangan desa secara tepatwaktu.

\section{Keterbatasan}

Terdapat beberapa keterbatasan pada penelitian ini yang diras perlu untuk dipaparkan Keterbatasan pada ini adalah:

1) Data penelitian ini didapatkan melalui kuesioner dan tidak dilengkapi dengan wawancara. Jarak antar desa dikabupaten aceh selatan menjadi dalah satu penyebab kuesioner yang diberikan sulit untuk kembali.

2) Varibel independen pada penelitian ini hanya terdapat 3 variabel yaitu kapasitas sumber daya manusia, pemanfaatan teknologi serta pengendalian intern dalam melihat ketepatwaktuan pelaporan keuangan desa. Beberapa variabel lain yang dirasa mempengaruhi ketepatwaktuan pelaporan keuangan desa

\section{Saran}

Dari rangkuman kesimpulan dan saran penelitian ini terdapat beberapa saran:

1) Guna mendukung serta menguatkan penelitian ini, dirasa perlu untuk melakukan penelitian ulang guna melihat konsistensinya. Sehingga kemudian dapan menjadi perbandingan baik dari penggunaan sampel, teknik analisis serta teknik pengumpulan data

2) Perlu untuk dipertimbangkan variabel-variabel lain diluar penelitian ini yang dirasa berpengaruh terhadap ketepatwaktuan pelaporan keuangan desa.

3) Menambahkan teknik pengumpulan data dengan 
teknik wawancara disamping menggunakan teknik kuisioner guna meminimalisir permasalahan subjektivitas dan keseriusan responden.

\section{Daftar Pustaka}

Ariesta, F. (2013). Pengaruh Kualitas Sumber Daya Manusia, Pemanfaatan Teknologi Informasi, dan Pengendalian Intern Akuntansi Terhadap Nilai Informasi Pelaporan Keuangan Pemerintah Daerah (Studi Pada Satuan Kerja Perangkat Daerah di Kabupaten Pasaman Barat). Fakultas Ekonomi. Universitas Negeri Padang. Padang.

Arina Roshanti Edy Sujana \& Kadek Sinarwati. (2014). Pengaruh kualitas sdm, pemanfaatan ti, dan sistem Pengendalian intern terhadap nilai informasi pelaporan Keuangan pemerintah daerah. E-Journal SI Ak Universitas Pendidikan Ganesha Jurusan Akuntansi Program S1, Volume $1 \mathrm{~N}$.

Ghozali, I. (2016). Aplikasi Analisis Multivariete Dengan Program IBM SPSS 23 (Cetakan ke). Semarang: Badan Penerbit Universitas Diponegoro.

Hamzah, A. (2010). Pengaruh Ekspektasi Kinerja Ekspektasi Usaha, Faktor Sosial,Kesesuaian Tugas dan Kondisi-kondisi yang Memfasilitasi Pemakai terhadap Minat Pemanfaatan Sistem Informasi (Studi Empiris Pada Pemerintahan Kabupaten di Pulau Madura).

Indriasari, D., \& Narhatyo, E. (2008). Pengaruh Kapasitas Sumberdaya Manusia, Pemanfaatan Teknologi Informasi, Dan Pengendalian Intern Akuntansi Terhadap Nilai Informasi Pelaporan Keuangan Pemerintah Daerah (Studi Pada Pemerintah Kota Palembang dan Kabupaten Ogan Ilir). Simposium Nasional Akuntansi IX. Padang.

Jurnali, \& Supomo., B. (2002). Pengaruh Faktor Kesesuaian Tugas- Teknologi dan Pemanfaatan TI terhadap Kinerja Akuntan Publik. Jurnal Riset Akuntansi Indonesia., Vol.5 No., Hal: 214228.

Mirnayanti, Bandang, A., \& Damayanti, R. A. (2013). Pengaruh kapasitas Sumber Daya Manusia, Pemanfaatan Teknologi Informasi dan Pengendalian Intern Terhadap Nilai Informasi Pelaporan Keuangan Pemerintah Daerah (Studi
Pada Pemerintah Daerah Kabupaten Majene Sulawesi Barat).

Permendagri No 113 Tahun. Pengelolaan Keuangan Desa (2014).

PP No 60 Tahun 2008. Peraturan Pemerintah Republik Indonesai Nomor 60 Tahun 2008 Tentang Pengendalian Intern Pemerintah.

Sekaran, U. (2006). Metodologi Penelitian untuk Bisnis (Buku 2, Ed). Jakarta: Salemba Empat.

Serambinews.com. (2018). Ini 10 Penyebab Dana Desa Macet Artikel ini telah tayang di serambinews.com dengan judul Ini 10 Penyebab Dana Desa Macet.

Sudarmanto, R. . (2013). Statistik Terapan Berbasis Komputer: Dengan Program IBM SPSS Statistik 19. Mitra Wahana Media.

Suwardjono. (2005). Teori Akuntansi: Perekayasaan Pelaporan Keuangan (Edisi Keti). Yogyakarta: BPFE.

Trisaputra, A. (2008). Pengaruh Pemanfaatan Teknologi Informasi dan Pengawasan Keuangan Daerah Terhadap Ketepatwaktuan Pelaporan keuangan Pemerintah Daerah (Studi Empiris pada SKPD Pemerintah Provinsi Sumatera Barat).

Tyas, A. P. (2014). Pengaruh Sumber Daya Manusia, Pemanfaatan Teknologi Informasi dan Pengendalian Intern Terhadap Ketepatwaktuan Pelaporan Keuangan Daerah (Studi Empiris pada Dinas Pendapatan, Pengelolaan Keuangan dan Aset Daerah di Wilayah Eks Karesidenan Surakarta ).

Wansyah, H., Darwanis, \& Bakar, U. (2012). PENGARUH KAPASITAS SUMBER DAYA MANUSIA, PEMANFAATAN TEKNOLOGI INFORMASI DAN KEGIATAN PENGENDALIAN TERHADAP NILAI INFORMASI PELAPORAN KEUANGAN SKPD PADA PROVINSI ACEH, 1(1), 43-58.

Winidyaningrum, C., \& Rahmawati. (2010). Pengaruh Sumber Daya Manusia dan Pemanfaatan Teknologi Informasi Terhadap Keterandalan dan Ketepatwaktuan Pelaporan Keuangan Pemerintah Daerah dengan Variabel Intervening Pengendalian Intern Akuntansi (Studi Empiris di Pemda SUBOSUKAWONOSRATEN). Simposium Nasional Akuntansi XIII.

Yosefrinaldi. (2013). Pengaruh Kapasitas Sumber 
Daya Manusia dan Pemanfaatan Teknologi Informasi Terhadap Kualitas Laporan Keuangan Pemerintah Daerah Dengan Variabel Intervening Sistem Pengendalian Intern Pemerintah (Studi Empiris Pada Dinas Pengelolaan Keuangan dan Aset Daera. Fakultas Ekonomi. Universitas Negeri Padang. Padang.

Yudiananta, \& Erawati. (2012). Yudiananta \& Erawati. 2012. Pengaruh Sumber Daya Manusia, Teknologi Informasi, dan Pengendalian Internal Terhadap Kualitas Laporan Keuangan. E-Jurnal Akuntansi Universitas Udayana, Vol 1 